\title{
Hur många miljöaktivister krävs det för att byta en glödlampa?
}

\section{Av Karin Filipsson}

I en värld där vi är medvetna om hur miljöproblemen påverkar oss, tar allt fler forskare och författare steget över tidigare strikt åtskilda discipliner och genrer för att diskutera och problematisera sambanden mellan kultur och natur, mellan litteratur och miljövetenskap. Glen A. Love hävdar i sin bok Practical Ecocriticism - Literature, Biology, and the Environment (2003) att det både är fruktbart och nödvändigt att utveckla ett närmare samarbete mellan teoretisk litteraturkritik och praktisk miljövetenskap som till exempel ekologi och biologi. Love menar att istället för att se på humaniora och naturvetenskap som vitt skilda kunskapsfält bör vi se sambanden dem emellan: "Nature interacts with cultural influences in shaping human attitudes and behavior" (Love 2003:8). Love betonar värdet av att kombinera litterära perspektiv på till exempel mänskliga värderingar och beteenden med naturvetenskapens kunskap om naturens funktioner: "Teaching and studying literature without reference to the natural conditions of the world and the basic ecological principles that underlie all life seems increasingly shortsighted, incongruous" (Love 2003:16).

I den här artikeln diskuteras skillnaden, eller snarare den imaginära motsättningen mellan litterärt skapande och aktivism, mellan fakta och fiktion, samt mellan olika typer av kunskap hos ursprungsbefolkningar i relation till vetenskapliga rön. Framför allt fokuserar jag på kunskapsskapande som en del av maktstrukturer och hur synen på kunskap påverkar debatten om de globala miljöproblemen. En naturlig följdfråga i den här diskussionen berör litteraturens värde som en viktig röst $i$ världen och huruvida gränsöverskridanden både mellan genrer och mellan litteratur och aktivism är en möjlig väg att gå för att utveckla diskursen om miljö och litteratur. Arundhati Roy och Amitav Ghosh är två indiska författare som har överskridit gränsen mellan fakta och fiktion, mellan konst och politik. Roy har skrivit en världsberömd roman, The God of Small Things (1997) som vann det årets Man Booker Prize. Därefter har hon publicerat flera samlingar med politiska essäer samt varit aktiv som miljöaktivist, speciellt i protesterna mot det berömda dammbygget Namada Dam Project i Indien men även i andra frågor som till exempel kärnvapen och antiglobaliseringen. Roy bor och arbetar fortfarande i Indien, medan Ghosh för närvarande är verksam i USA som författare och litteraturprofessor. Ghosh är författare till en rad välkända romaner i olika genrer, bland annat The Circle of Reason (1986), The Shadow Lines (1990), The Calcutta Chromosome (1995) och The Glass Palace (2000). Han har en doktorsexamen i antropologi och hans bok In an Antique Land (1994) är en blandning av fiktion och faktarapport från hans resor med insamlande av material till hans doktorsavhandling. Ghosh har även publicerat flera essäsamlingar om ämnen som kärnvapen och miljöfrågor. 
Arundhati Roy skriver i sin essäsamling Power Politics: "In the early days, I used to be described - introduced - as the author of an almost freakishly 'successful' (if I may use so vulgar a term) first book. Nowadays I'm introduced as something of a freak myself. I am, apparently, what is known in twenty-first-century vernacular as a 'writer-activist' (Like a sofa-bed)" (Roy 2001:10). Roy diskuterar frågan om det är ett nödvändigt krav att författare av skönlitteratur ska vara neutrala och om det är rimligt att de bemöts med misstänksamhet ifall de tar ställning och tydligt visar att de har en åsikt: "But is it mandatory for a writer to be ambiguous about everything?" (Roy 2001:12). Roy hävdar i sin essä att problemet tycks vara behovet hos omvärlden att etikettera skribenter och författare som antingen eller: 'I've been wondering why it should be that the person who wrote The God of Small Things is called a writer, and the person who wrote the political essays is called an activist? True, The God of Small Things is a work of fiction, but it's no less political than any of my essays" (Roy 2001:10 -11). Ghoshs roman The Hungry Tide (2004) och hans essä "The Town by the Sea" ur essäsamlingen Incendiary Circumstances - A Chronicle of the Turmoil of our Times (2005) behandlar samma typ av problem i samma del av världen, nämligen flodvågor i Sydostasien, fast i olika genrer, fiktion respektive icke-fiktion. I essän "The Town by the Sea", där Ghosh beskriver sitt besök i samma område som romanen utspelar sig i, Andaman och Nicobaröarna, möter Ghosh människor som blivit drabbade av tsunamin i december 2004. I slutet av essän beskriver Ghosh hur orden inte räcker till: "There are times when words seem futile, and to no one more so than a writer. At these moments it seems that nothing is of value other than to act and to intervene in the course of events" (Ghosh 2005:23).

I sin bok Amitav Ghosh (2007) påpekar Anshuman A. Mondal att Ghosh i sitt arbete konsekvent har överskridit genregränser. Mondal säger: 'Indeed, it is probably not wise to distinguish between his fiction and non-fiction as it is perhaps another one of those artificial boundaries that Ghosh consistently interrogates" (Mondal 2007:19). Mondal hävdar att Ghosh genom att växla mellan olika genrer och blanda fakta och fiktion, ofta i samma verk, iscensätter en metod som kan beskrivas som ett försök till motstånd mot de strukturer som definierar litteraturens form: "Many of his works seek to deconstruct, or at least put into question, the value of distinguishing between 'fact' and 'fiction'. For to speak of 'facts' immediately involves some taxing epistemological problems: whose 'facts'? In whose interests are 'facts' deployed? For what purpose?' (Mondal 2007:19). Enligt Mondal kan Ghoshs arbete tolkas som en del av ett postkolonialt motstånd och ett ifrågasättande av hur, och av vem, frågor som kunskap, fakta, fiktion och även språk värderas och definieras.

I romanen The Hungry Tide problematiserar Ghosh den diskrepans som finns mellan västerländska, välmenande miljöaktivisters försök att skapa naturreservat för att bevara utrotningshotade tigrar i Sydostasien och hur det påverkar lokalbefolkningen, vars liv bokstavligen hotas av tigrarnas existens i deras närmiljö. Mondal säger: "The Hungry Tide is a novel which foregrounds language and textuality, and its relationship to lived experience. What, it asks, is environmentalism in the abstract worth?" (Mondal 2007:19). I romanen drabbas 
den besökande, amerikanska naturforskaren Piya av en chock vid mötet med lokalbefolkningens grymma behandling av en infångad tiger. Hennes guide Kanai som har det symboliska yrket översättare, försöker förklara - översätta - situationen för Piya: "Piya, you have to understand - that animal's been preying on this village for years. It's killed two people and any number of cows and goats " (Ghosh 2004:294). Piya är förfärad över att tigern har tillfångatagits och att man dessutom sätter eld på den. Kanai gör sitt bästa för att trösta Piya: "Fokir says, you shouldn't be so upset." Piya replies: "How can I not be upset? That's the most horrifying thing I've ever seen - a tiger set on fire." Kanai fortsätter att översätta mellan två världar och vidarebefordrar till Piya vad Fokir säger till honom: "He says, when a tiger comes into a human settlement, it's because it wants to die." Piyas enda reaktion på det här är att vända sig bort i förtvivlan, med händerna för öronen: "She turned to Fokir, covering her ears with both hands. 'Stop it. I don't want to hear any more of this. Let's just go'"(Ghosh 2004:295). Ghoshs roman komplicerar diskussionen om vems kunskap som är mest avgörande, mest "sann" och visar på hur komplex bilden av miljöproblem, naturreservat och relationen mellan djur och människor är beroende på kontexten och från vems synvinkel man ser på situationen. Genom att problematisera miljöproblemen konkretiserar Ghoshs roman svårigheten att välja rätt väg för att lösa globala problem och hur viktigt det är att analysera bakgrunden och framför allt diskutera vem som har makten att definiera begrepp som kunskap och sanning.

Amerikanska författare som skriver i genren som kallas "nature writing" är av tradition genreöverskridande och många av genrens mest kända verk är en blandning av fakta och fiktion, ofta kallad "creative non-fiction". Dessutom är det inte ovanligt att författare inom den här genren i USA också är miljöaktivister. Den här traditionen sträcker sig tillbaka till Henry David Thoreau som skrev den naturlyriska boken Walden (1854) samt skriften Resistance to Civil Government (1849), ett upprop mot amerikanskt rättsväsende. En av de mest omdiskuterade författarna, just på grund av att han överskrider gränsen mellan naturromantisk filosofi och miljöaktivism, är Edward Abbey som inleder sin bok Desert Solitaire - A Season in the Wilderness med de poetiska orden: "This is the most beautiful place on earth" (Abbey 1968:1). Boken handlar om hur Abbey, som arbetar i ett naturreservat, lever i och observerar naturen på nära håll, samtidigt som han är starkt kritisk till turism och statligt handhavande av naturresurserna. Han är i sin bok särskilt kritisk till dammbygget vid Glen Canyon. I Abbeys senare roman The Monkey Wrench Gang (1975), iscensätter karaktärerna den typ av attentat mot dammbygget som diskuteras i Desert Solitaire. Även om Abbey själv har påstått att romanen ska tolkas som en satir, har den blivit en inspirationskälla för diverse miljöaktivister.

Den amerikanske miljöaktivisten och debattören Derrick Jensen diskuterar i sin bok Endgame (2006) frågan om författarens och språkets roll i samhället och i vilken utsträckning vi tillräckligt ofta och tillräckligt medvetet analyserar hur makt och kultur är sammanvävda och uttrycks via språk och texter. I likhet med Roy, Ghosh och Mondal påpekar Jensen att värdet av den text som en författare producerar alltid definieras i enlighet med en kultur och en struktur. Jensen säger: "All writers are propagandists" (Jensen 2006:722). Jensen menar 
att till och med definitionerna av enstaka ord i ordböcker är influerade av samhälleliga och kulturella maktstrukturer och att det är svårt, för att inte säga omöjligt, att undkomma dessa strukturer som vi är en del av. Jensen relaterar den här diskussionen till både koloniala och patriarkala maktstrukturer samt till människors relation till naturen. I sin bok A Language Older than Words (2000), alluderar Jensen på Edward Abbeys radikala ståndpunkt rörande dammbygget vid Glen Canyon på 1960-talet, när han säger: "Every morning when I awake I ask myself whether or not I should write or blow up a dam. I tell myself I should keep writing, though I'm not sure that's right" (Jensen 2000:50). Jensens påstående är medvetet provokativt och av en annan kaliber än Roys och Ghoshs mer subtila ståndpunkter, men det som förenar dem är försöket att se sambandet mellan språk och makt och insikten att det är svårt att åstadkomma förändring när språk och text är sammankopplade med strukturer som neoimperialism och kolonisation. Att överskrida genregränser kan, såsom Mondal hävdar, vara ett försök till motstånd mot invanda formstrukturer och ett sätt att medvetet belysa sambanden mellan fakta och fiktion. Den här diskussionen väcker frågan om vem som har makten att definiera kunskap och vetenskap.

Den världsberömda miljöaktivisten och mottagaren av det alternativa Nobelpriset, The Right Livelihood Award 1993, Vandana Shiva, har skapat ett begrepp som hon kallar Earth Democracy, vilket är en modell för ett hållbart demokratiskt, ekologiskt samhälle där decentralisering är avgörande för att tillgodose behovet av lokal kunskap och lokalt miljötänkande, som kontrast till den globalisering av marknadskrafterna som har sin utgångspunkt i Västvärlden. Shiva är från början fysiker och har i sitt arbete överskridit gränserna mellan lokalt och globalt samt mellan västerländsk vetenskap och kunskap baserad på urbefolkningens jordbruksmetoder och ekologiska tänkande. I hennes fall handlar det inte om genreöverskridande utan om ett gränsöverskridande i fråga om hur kunskap och vetenskap definieras och tillvaratas. Shiva fokuserar i sitt arbete på att utgå från småskalighet och hur lokala jordbrukare i Indien, framför allt kvinnor, producerar grödor i enlighet med ett ekologiskt synsätt. I sin bok Earth Democracy - Justice, Sustainability, and Peace (2005) ifrågasätter Shiva invanda strukturer och antropocentriska sätt att se på naturen: 'Patents on life and the rhetoric of the 'ownership society' in which everything - water, biodiversity, cells, genes, animals, plants - is property express a worldview in which life forms have no intrinsic worth, no integrity, and no subjecthood." (Shiva 2005:3) Det finns stora likheter mellan Shivas perspektiv på äganderätt till naturen och en av de mest kända föregångarna inom den amerikanska miljörörelsen, författaren Aldo Leopold. Han presenterar i sin bok A Sand County Almanac (1949) en så kallad 'Land Ethic". Det är en ekologisk morallära som syftar till att få människor att avlägsna sig från ett antropocentriskt perspektiv och att sluta se naturen och jorden som sin rättmätiga egendom. Aldos syfte är att människor ska behandla naturen som ett ansvarsområde med ett eget värde, jämlikt med människan: 'The land ethic simply enlarges the boundaries of the community to include soils, waters, plants, and animals, or collectively: the land" (Leopold 1949:204). Leopolds bok är precis som Jensens och Shivas böcker en blandning av naturobservationer, filosofi och miljöetik. 
Sammanfattningsvis följer såväl Vandana Shiva och Derrick Jensen en tradition av genreoch gränsöverskridanden som har varit en del av miljö-, filosofi- och etikrörelsen sedan Aldo Leopolds och Edward Abbeys tid. Arundhati Roy och Amitav Ghosh bryter mönstret då de tar avstamp i sitt skönlitterära skapande för att öppna vägar mot en ny diskurs där de deltar med politiskt engagerade och filosofiskt-etiska essäer, ofta inriktade på miljöfrågor, som ett komplement till, eller snarare en utveckling av sitt skönlitterära författarskap. På det viset är de gränsöverskridande eftersom de pekar på värdet av att söka sig nya vägar och kanaler för att debattera väsentliga frågor i världen idag. Deras skapande av icke-fiktion blir inte bara ett tillägg, utan i ett vidare perspektiv en del av ett utvidgande av den rådande diskursen om litteratur och miljöproblem. Kunskap, vetenskap och maktstrukturer tematiseras frekvent i Ghoshs romaner, vilket gör att hans essäer också blir en viktig del av en analys av hela författarskapet och dess implikationer i stort.

Titeln på den här artikeln alluderar på en fråga som Derrick Jensen påstår sig ha fătt av en åhörare vid ett av sina föredrag om miljöaktivism: Hur många miljöaktivister krävs det för att byta en glödlampa? Jensens svar löd: Tio, varav nio skriver artiklar och upprop för aktioner, brev till makthavare, håller föredrag med mera och slutligen en som i otålig frustration över bristen på resultat slår sönder glödlampan. Min slutsats är att de som arbetar med skrivande exemplifierar poängen med den här artikeln, nämligen att det finns olika sätt att arbeta för en bättre global miljö, och att de vidareutvecklar både den politiskt inriktade miljödebatten och kompletterar och utvidgar den litterära diskursen om sambandet mellan kunskap, språk och makt.

\section{Källförteckning}

Abbey, Edward. 1968. Desert Solitaire - A Season in the Wilderness. New York: Random House Publishing Group.

Ghosh, Amitav. 2005. Incendiary Circumstances - A Chronicle of the Turmoil of Our Times. New York: Houghton Mifflin Company.

Ghosh, Amitav. 2004. The Hungry Tide. London: Harper Collins Publishers.

Jensen, Derrick. 2000. A Language Older than Words. Chelsea Green Publishing Company. Jensen, Derrick. 2006. Endgame. Seven Stories Press.

Jensen, Derrick. 2007. 'How many environmentalists does it take to change a lightbulb?". YouTube. August 07, 2007.

Leopold, Aldo. 1949. A Sand County Almanac. New York: Oxford University Press.

Love, Glen A. 1993. Practical Ecocriticism - Literature, Biology, and the Environment.

Charlottesville and London: University of Virginia Press.

Mondal, Anshuman A. 2007. Amitav Ghosh. Manchester: Manchester University Press.

Roy, Arundhati. 2001. Power Politics. Cambridge: South End Press.

Shiva, Vandana. 2005. Earth Democracy - Justice, Sustainability, and Peace. Cambridge: South End Press.

Thoreau, Henry D. 1966. Walden and Resistance to Civil Government, 2nd ed. New York and London: W.W. Norton \& Company, Inc. 